\title{
Spreading Systems Engineering and Engineering Management Know-How Across Capstone Design: A Comparison of an Existing Course to a Pilot
}

\section{Dr. Kate D. Abel, Stevens Institute of Technology (SES)}

Kate Abel serves as the as the Director of the Bachelor of Engineering in Engineering Management Program in the School of Systems and Enterprises at Stevens Institute of Technology. She holds a Ph.D. in Technology Management and Applied Psychology. She has held several professional service positions including the President of the Engineering Management Division of the American Society for Engineering Education and the President of Epsilon Mu Eta, the Engineering Management Honor Society. She teaches courses in Total Quality Management, Engineering Economics, Entrepreneurial Analysis of Engineering Design, Statistics for Engineering Managers, Management of Engineering and Technology, and Senior Design. Her research areas include knowledge engineering, as well as, knowledge and information management. She has been published several times including chapters in the books Eshbach's Handbook of Engineering Fundamentals and Engineering Economic Analysis; in journals such as the Engineering Management Journal and the Journal of Engineering Education; and several conference proceedings. She is a member of the Board of Advisors at West Point for the Department of Systems Engineering. She is also a member of several professional societies including ASEE, ASEM, ASME, and EMH. 


\title{
Spreading Systems Engineering and Engineering Management Know-How Across Capstone Design: A Comparison of an Existing Course to a Pilot
}

\begin{abstract}
About a decade ago, a movement was started at Stevens Institute of Technology to infuse the Capstone experience with Systems Engineering (SE) and Engineering Management (EM) knowledge. However the discipline specific Senior Design advisors did not have the time to teach, nor the in-depth awareness of, SE and EM topics to be able to provide their students with substantive learning on these subjects. A course soon emerged that would run along side the Senior Capstone Design course, to provide knowledge in these areas. The course exists in two formats. One format has been running for years as a traditional 3-credit, one semester course. The other format was implemented recently as a pilot to provide just-in-time learning over both semesters of senior design. Both formats have been running concurrently for three years. This article will address how the needs of the Senior Design Advisors from the various disciplines were married to Systems Engineering and Engineering Management topics and deliverables to create two versions of a course to improve the overall functionality of all Capstone design teams, as well as, their project's final outcome. To conclude, the benefits/disbenefits and success/lack of success of the two different formats is highlighted.
\end{abstract}

\section{Background}

It has long been the bane of many an employer, systems engineer or Engineering Management professional, that traditionally trained engineers lack the breadth and understanding necessary to succeed in business settings. Often the engineer sees the technology, but fails to see how the technology can benefit the business, or how the technology can benefit the business beyond just the technology. It is these types of critical analytical skills, as well as teamwork, communication and project management skills that many say are missing from the traditional engineering education (Felder, Vest, etc). Authors like Sheppard, et. al. advocate for modifying the engineering classroom to allow ways these skills can be taught.

Success in business is determined by the technical skills within the organization. However, success of a business is also based on those employees having an understanding of what the business really needs. Technical professionals need to be better attuned to customer needs and stakeholders' perspectives, in order to align technical progress with business strategy. Such real world understanding is missing from traditional engineering education. Many say that the Capstone Design experience is supposed to be where this real-world, integration and culmination of all that has been learned is supposed to take place. However, many a Senior Capstone Advisor will tell you that they barely have enough time (either with the team or within their own jobs) to adequately cover the technical components of each capstone design. Thus sadly, the realworld aspects of capstone design are mostly pushed aside, or just not delved into in 
exchange to allow focus on the technology. This is exactly what our engineers do NOT need reiterated into their heads - only the technology matters, all else can be pushed aside - but this is just what today's engineering education is saying to them.

At Stevens, an opportunity was seen in this regard. Senior Capstone Design coordinators saw the need to widen their students' breadth of knowledge about the real-world aspects necessary to good design. Senior Capstone Design Coordinators also saw their teams fail to address basic EM and SE concepts that would have made the team's solution even more successful. However, the capstone coordinators did not have the time nor the indepth knowledge necessary to integrate such applications into their capstone design teams, so a course was created.

\section{Population}

Stevens Institute of Technology is a small, private, urban campus across the Hudson River from Manhattan in New Jersey. Approximately 3000 undergraduate students are enrolled, of whom about 2000 are engineering students. There are two versions of the "Innovation and Entrepreneurship" course currently being taught to the engineering students. Nine engineering programs exist at Stevens - Bio-Medical, Civil, Chemical, Computer, Electrical, Engineering Management, Environmental, Mechanical, Navel Engineering. All 9 programs participate in one version of the course. Six participate in both versions. Both single discipline teams and multi-disciplinary teams participate in the Senior Engineering Capstone design experience with projects varying widely between disciplines from design of physical structures for Civil Engineers to design of systems for Engineering Managers, for example. The Engineering Management Program housed in the School of Systems and Enterprises at Stevens was called upon to instruct both versions of the "Innovation and Entrepreneurship" course based on the needs of the Senior Capstone Design coordinators, as well as the needs readily apparent of all the engineering students in general.

\section{Methodology and Differences Between Formats}

The capstone design course is spread over two semesters of the senior year and was originally 4 credits in the fall and 6 in the spring (total of 10). This was seen as too many credits and frankly some faculty used grade inflation to prevent having a devastating (10 credit) impact of a low grade on their student's GPA. For the new course, capstone design was reduced to 3 credits in each semester (total of 6). And three of the extra credits were transitioned into an "Innovation and Entrepreneurship" course, which would run side by side with the capstone design course in one of two formats.

One format called TG 421- Entrepreneurial Analysis of Engineering Design, runs the 3credit course in one semester, and has been running this way for many years. Most seniors take this course in the fall as they begin their capstone design. TG 421 is run as larger sections (50 to 100 students) with about 5 workshops imbedded in the course. 
The second format, TG 403/404 - Senior Innovation 1 and 2, runs as two courses over two semesters, applying 2 credits to the fall and one credit to the spring. TG 403/404 is run in smaller sections (15 to 35 students) with about as many workshops imbedded in the two courses as there are lessons. This course set has been run in pilot mode since the Fall of 2012. The goal of the new TG 403/404 pilot being spread over two semesters was to provide just-in-time EM and SE knowledge to the seniors as they completed their twosemester capstone design sequence.

The Senior Capstone Design Coordinators were quite cognizant that many of their students did not have good planning and project management skills. They also were readily aware of how "green" their students were in regard to preparedness in meetings with clients, and that very few teams designed with cost in mind. So their focus, understandably so, was on their capstone design teams' understanding of Gantt Charts, setting agendas, mission statements, voice of the customer, etc. However, knowing that these concepts were only the tip of the iceberg, the School of Systems and Enterprises added in coverage of topics from Engineering Management and Systems Engineering, such as Project Management, Systems Thinking and Engineering Economy. Additionally, the courses were implemented in a way to ensure the students would not just be introduced to the topics, but would understand the importance of WHY they were learning these topics as well.

TG 421 has been taught by the School of Systems and Enterprises since its inception. The School of Systems and Enterprises joined the team of TG 403/404 instructors in Fall of 2103, and eventually took over the course entirely in the Fall of 2014. The final list of topics and deliverables in the Innovation and Entrepreneurship courses were reviewed and coordinated with the Senior Capstone Design Coordinators. Please see Exhibit 1 below, which lists topics and the questions students were urged to consider relevant to the topics. 
Exhibit 1 - The Whole System - From Original Need to Final Product

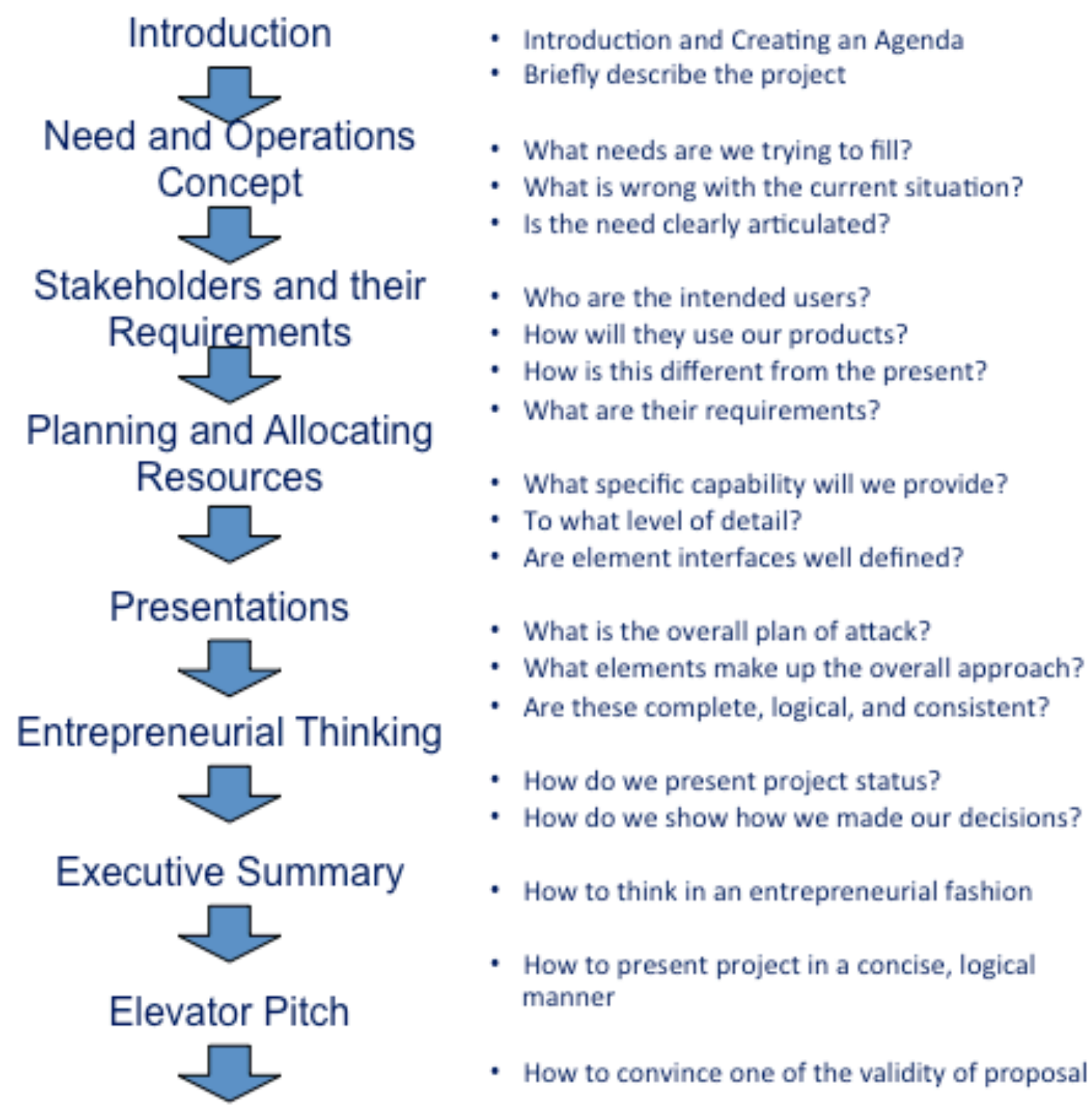

Please see Appendix A for a week-by-week breakdown of topics and submittals in both TG 403/404 and TG 421.

Note from the breakdown of the two courses in Appendix A, that there was approximately $90 \%$ overlap in materials, course content and deliverables between the two courses. For example, both courses required the following deliverables: Value Proposition, Mission Statement, Gantt Chart, Stakeholder Needs Analysis, Competitive Intelligence Analysis, Business Plan, Financial Analysis, Elevator Pitch (Preliminary and Final) and a Presentation. Each deliverable was instructed not just on the topic, but by demonstrating how such analyses benefit the team in helping them to create a better design: a design that fits the needs and costs of the producer and user, not just the desires of the designer. 
The major difference between the two courses lay in the format and approach taken. The two different formats (example, spread of credits, and one semester vs. two) have already been detailed above in this section of the paper. But the approach taken was also very different in the two courses. The basic difference comes down to the flexibility and workload that was provided in TG 421 , as compared to the just-in-time rigidity of TG $403 / 404$ and its multitude of deliverables.

TG 421 taught "Entrepreneurial Analysis" of any type of design in any engineering major - focusing on thinking out of the box as to the student's approach to design, rather than on a deliverable/assignment. TG 403/404 taught "Innovation" in terms of design. Students had issue with this second approach as many felt they would never be inventors, or that their specific capstone design project was not entrepreneurial. As such many students felt disconnected from the course.

TG 421 required submission of deliverables in groupings. For example, instead of having an assignment due every week, several topics were grouped together and assignments were due about every second or third week. The same was true of workshops. TG 403/404, on the other hand, had assignments due every week on the preceding topic, as well as, workshops every week on the current topic.

Ironically, the just-in-time nature of TG 403/404 was the whole impetus behind the creation of the 403/404 course pilot. However, it seemed to be its' downfall, as well. Requiring so many workshops and so many deliverables and only providing the students two credits worth of course load for the multitude of assignments made the students approach the course with apathy and perceive the course as drudgery. Combine that with the disconnect from the students who felt they would never be "inventors", and it is understandable why assessment of the TG 403/404 pilot showed it was not very successful in achieving it's outcomes.

\section{Results}

Data regarding the success of the two versions of Innovation and Entrepreneurship was collected each year via an on-line assessment system. For TG 421 the data was always collected systematically as ABET requires. Longitudinal scores of course outcomes for both formats are listed below in Table 1. During the early pilot stages of TG 403/404, data was only collected via paper surveys to assess impact, not learning, as such several boxes of TG 403/404 outcomes data in Table 1 are empty. Scores range from 0 to 4 on a Likert type scale and have been aggregated from multiple instructors in order to list them per semester. Please see Appendix B for the full course outcome for each of the ABET a$\mathrm{k}$ listed below and what deliverable was used to measure each outcome. 
TABLE 1 - Course Outcomes Assessment

\begin{tabular}{|l|l|l|l|l|l|}
\hline & $\begin{array}{l}\text { Fall } \\
2012 *\end{array}$ & $\begin{array}{l}\text { Spring } \\
2013\end{array}$ & Fall 2013 & $\begin{array}{l}\text { Spring } \\
2014\end{array}$ & Fall 2014 \\
\hline TG 403 & & & & & \\
\hline - Tools (k)+ & & & & & 2.70 \\
\hline - Professionalism (f) & & & & & 2.69 \\
\hline - Leadership (d) & & & & & 2.61 \\
\hline - Teamwork (d) & & & & & 2.63 \\
\hline - Communication (g) & & & & & 2.63 \\
\hline - Social Issues (j,h) & & & & & 2.48 \\
\hline - Entrepreneurship & & & & & 2.58 \\
\hline & & & & & \\
\hline TG 421 & & & & & \\
\hline - Design Assessment \\
(c,h)
\end{tabular}

*Column intentionally left blank. TG 421 had completely new material in Fall of 2012. However, due to delayed communication, the outcomes were not changed in the Stevens Assessment System prior to students filling out the Fall 2012 course assessments. As such the outcomes did not match what was actually taught in the TG 421 class for Fall of 2012. Thus the outcomes scores for Fall 2012 are not listed here.

+ Letters in parentheses indicate correlation to ABET a-k

In addition to the above data on course outcomes, student input on course quality is also valued and therefore collected. From Stevens' assessment system, the following student feedback on course quality is summarized in Table 2. Again, Course Quality ratings as perceived by the students range from 0 to 4 on a Likert type scale and have been aggregated from multiple instructors in order to list them per semester.

TABLE 2 - Course Quality

\begin{tabular}{|l|l|l|l|l|l|}
\hline & Fall 2012 & Spring 2013 & Fall 2013 & $\begin{array}{l}\text { Spring } \\
2014\end{array}$ & Fall 2014 \\
\hline TG 403 & 2.63 & n/a & 2.85 & n/a & 2.91 \\
\hline TG 404 & n/a & 2.34 & n/a & 2.84 & n/a \\
\hline TG 421 & 2.95 & 3.29 & 3.27 & 3.60 & 3.57 \\
\hline & & & & & \\
\hline
\end{tabular}


Some may say that there could be bias in the data above since more than one instructor was used for instruction. Said another way, it could be construed that the instructors themselves may have played a role in the significant difference between the scores of TG 403/404 and TG 421. Please see Table 3 below that lists the Instructor Evaluation scores for both courses. Again, Instructor evaluation ratings as perceived by the students range from 0 to 4 on a Likert type scale and have been aggregated from multiple instructors in order to list them per semester. For TG 403/404, note the significant rise in Instructor evaluation scores in Fall 2013, which was the same semester the School of Systems and Enterprises (SSE) joined the instructional team of TG 403/404. This influx of new teaching faculty into TG 403/404 in Fall 2013 may account for the bump in Course Quality Scores in the same time period (Table 2 above), actually inflating the TG 403/404 Course Quality scores above what they would have been without these SSE instructors. Additionally, note that the two instructors of TG 421 (average Instructor score of 3.41) are also two of the instructors for TG 403/404 (average Instructor score from when they joined the instructional team of 3.15). And these two instructors again may actually inflate the TG 403/404 Course Quality scores (Table 2) above what they would have been without these two instructors. Thus, without the School of Systems and Enterprises instructors, the difference in Course Quality between TG 403/404 and TG 421 would most likely have been even greater.

Table 3 - Instructor Evaluation

\begin{tabular}{|l|l|l|l|l|l|}
\hline & Fall 2012 & Spring 2013 & Fall 2013 & $\begin{array}{l}\text { Spring } \\
2014\end{array}$ & Fall 2014 \\
\hline TG 403 & 2.82 & n/a & 3.10 & n/a & 3.24 \\
\hline TG 404 & n/a & 2.35 & n/a & 3.12 & n/a \\
\hline TG 421 & 2.99 & 3.34 & 3.40 & 3.70 & 3.60 \\
\hline
\end{tabular}

Stevens also collects student comments on specific lectures and overall course performance. It is certain that for every negative there is at least one positive (or more) as both formats of the course are graded above 2.5 (out of 4) consistently over the years. Students in both versions also said the workshops were useful. But there is some noticeable variation in comments and scoring between the two versions. Please see the comments below that summarize student opinion regarding the two formats.

TG 403/404 (2/1 credit, two semester version)

- This course is diluted. The material should be taught in one semester.

- The lectures were good, but the lecture material was not applicable to all senior design projects. Not all senior design projects are really viable as businesses.

TG 421 (3 credit, one semester version)

- I believe everyone should take a course like this - not just the engineers.

- This class helped facilitate a lot of unknowns and brought out a lot of the important processes associated with building an idea into a product. 
Lastly, the culmination of both formats of the Innovation and Entrepreneurship course is the Senior Design Innovation Expo Day that highlights more than a 100 single discipline and interdisciplinary student research projects each year. The highlight of this day is a formal Elevator/Project Plan Pitch competition between the capstone design teams with over $\$ 12,000$ in prizes. As mentioned above in Exhibit 1 and the Appendices, the elevator/project plan pitch is a deliverable in both versions of the Innovation and Entrepreneurship Course. Please see http://www.stevens.edu/provost/oie/2013InnovationExpoCompetition for the 2013 Pitch Competition winners.

\section{Conclusions and Recommendations}

The data as well as the students' comments clearly show a discernable difference between the two versions of the Innovation and Entrepreneurship course. The course outcomes' assessment and course quality scores were both significantly lower for TG 403/404. And many of those students taking the two-semester TG 403/404 course felt that the material could have been better incorporated into a one-semester course.

Additionally, upon parsing the student comments, it becomes clear that TG 403/404 is not applicable to some types of engineering. Specifically Civil, Mechanical and Chemical Engineering students claim that TG 403/404 is not applicable to their capstone design projects and that these disciplines should remain in the well-established TG 421 course. It is by these and other disciplines' own testimonials both against and for TG 403/404 that TG 403/404 should be run only for interdisciplinary, start-up-like capstone design teams.

Thus, in conclusion there appears to be benefits to both versions of instruction in Innovation and Entrepreneurship. TG 403/404 provides a strong and appreciated foundation in entrepreneurial understanding for multidisciplinary, commercializable designs. However, not all Senior Capstone Designs are of this type. TG 421, on the other hand, provides a backbone of understanding for thinking outside the box, for all types and disciplines of capstone design that are innovative, without necessarily being entrepreneurial.

\section{References}

Felder, Richard M., "Engineering Education: A Tale of Two Paradigms", $<$ http://www4.ncsu.edu/unity/lockers/users/f/felder/public/Papers/TwoParadigms.pdf $>$

Vet, Charles M., "Educating Engineers for 2020 and Beyond”, National Academy of Engineering, < http://engineeringchallenges.org/cms/7126/7639.aspx $>$.

Sheppard, S.D., Macatangay, K., Colby, A., \& Sullivan, W.M. 2008. Educating engineers: Designing for the future of the field. New York: John Wiley \& Sons. 
Appendix A

\section{TG 403 - Senior Innovation I Schedule}

\begin{tabular}{|c|c|c|c|}
\hline Week & Lecture Topic & Workshop & Deliverable \\
\hline 1 & Introduction to Managing Projects & $\begin{array}{l}\text { Meeting Agenda } \\
\text { Workshop }\end{array}$ & \\
\hline 2 & $\begin{array}{l}\text { Mission Statement } \\
\text { Identifying Stakeholders }\end{array}$ & $\begin{array}{l}\text { Mission Statement } \\
\text { Workshop }\end{array}$ & $\begin{array}{l}\text { Lab } 1 \text { - Meeting } \\
\text { Agenda and Org. } \\
\text { Chart }\end{array}$ \\
\hline 3 & Presentation Basics & $\begin{array}{l}\text { Identify Project } \\
\text { Stakeholders Workshop }\end{array}$ & $\begin{array}{l}\text { Lab } 2 \text { - Mission } \\
\text { Statement }\end{array}$ \\
\hline 4 & Prioritizing Stakeholder Needs & $\begin{array}{l}\text { Stakeholder Needs } \\
\text { Analysis Workshop }\end{array}$ & $\begin{array}{l}\text { Lab } 3 \text { - Stakeholder } \\
\text { List }\end{array}$ \\
\hline 5 & Resource Planning and Scheduling & $\begin{array}{l}\text { Project Schedule } \\
\text { Workshop }\end{array}$ & $\begin{array}{l}\text { Lab } 4 \text { - Stakeholder } \\
\text { Needs Analysis }\end{array}$ \\
\hline 6 & $\begin{array}{l}\text { From Business Model to Business } \\
\text { Plan }\end{array}$ & $\begin{array}{l}\text { Lean Canvas Business } \\
\text { Plan Workshop }\end{array}$ & $\begin{array}{l}\text { Lab } 5 \text { - Project Plan } \\
\text { for the Year }\end{array}$ \\
\hline 7 & Management of IP Guest Lecture & & $\begin{array}{l}\text { Lab } 6 \text { - Lean Canvas } \\
\text { Business Plan }\end{array}$ \\
\hline 8 & Status Presentations & & $\begin{array}{l}\text { Team Status } \\
\text { Presentations }\end{array}$ \\
\hline 9 & Understanding your Customer & $\begin{array}{l}\text { Competitive Intelligence } \\
\text { Workshop }\end{array}$ & \\
\hline 10 & Review of Economics of a start up & $\begin{array}{l}\text { Financial Analysis } \\
\text { Workshop }\end{array}$ & $\begin{array}{l}\text { Lab } 7 \text { - Competitive } \\
\text { Intelligence }\end{array}$ \\
\hline 11 & Preparation for Presentations & Presentations Workshop & $\begin{array}{l}\text { Lab } 8 \text { - Financial } \\
\text { Analysis }\end{array}$ \\
\hline 12 & In Class presentations & & $\begin{array}{l}\text { Project Presentation } \\
\text { as per sign ups }\end{array}$ \\
\hline 13 & In class presentations & & $\begin{array}{l}\text { Project Presentation } \\
\text { As per sign ups }\end{array}$ \\
\hline
\end{tabular}




\section{TG 404 Senior Innovation II Schedule}

\begin{tabular}{|c|c|c|c|}
\hline Week & Lecture Topic & Workshop & Deliverable \\
\hline 1 & $\begin{array}{l}\text { Introduction to Entrepreneurship \& } \\
\text { course overview }\end{array}$ & & \\
\hline 2 & $\begin{array}{l}\text { Craft your value proposition: Elevator } \\
\text { Pitch } \\
\text { Failures in Entrepreneurship }\end{array}$ & $\begin{array}{l}\text { Value Proposition } \\
\text { Workshop }\end{array}$ & \\
\hline 3 & Executive Summary Workshop & $\begin{array}{l}\text { Executive Summary } \\
\text { Workshop }\end{array}$ & $\begin{array}{l}\text { Lab } 1 \text { - Value } \\
\text { Proposition }\end{array}$ \\
\hline 4 & $\begin{array}{l}\text { Identify and analyze your target } \\
\text { industry }\end{array}$ & & $\begin{array}{l}\text { Lab } 2 \text { - Executive } \\
\text { Summary }\end{array}$ \\
\hline 5 & Positioning your venture & $\begin{array}{l}\text { Executive Summary } \\
\text { Workshop }\end{array}$ & \\
\hline 6 & $\begin{array}{l}\text { Continuation of Economics of a } \\
\text { Startup }\end{array}$ & Workshop & $\begin{array}{l}\text { Lab } 3 \text { - Revised } \\
\text { Executive Summary }\end{array}$ \\
\hline 7 & Raising Capital & & $\begin{array}{l}\text { Lab } 4 \text {-Financial } \\
\text { Analysis - Part } 2\end{array}$ \\
\hline 8 & \multicolumn{3}{|c|}{ No Class - Spring Break } \\
\hline 9 & $\begin{array}{l}\text { Preparation for Innovation Expo } \\
\text { and Final Presentation } \\
\text { (no lecture, attendance taken, EP \& } \\
\text { Executive Summary Revising, etc) }\end{array}$ & Workshop & \\
\hline 10 & $\begin{array}{l}\text { Elevator/Project Pitch Presentations } \\
\text { First Attempt (based on sign ups) }\end{array}$ & & $\begin{array}{l}\text { Elevator/Project } \\
\text { Pitch - First } \\
\text { Attempt }\end{array}$ \\
\hline 11 & $\begin{array}{l}\text { Preparation for Innovation Expo } \\
\text { and Final Presentation } \\
\text { (no lecture, attendance taken, EP \& } \\
\text { Executive Summary Revising, etc) }\end{array}$ & Workshop & \\
\hline 12 & $\begin{array}{l}\text { Elevator/Project Pitch Presentations } \\
\text { Second Attempt (based on sign ups) }\end{array}$ & & $\begin{array}{l}\text { Elevator/Project } \\
\text { Pitch - Second } \\
\text { Attempt }\end{array}$ \\
\hline 13 & \multicolumn{3}{|c|}{$\begin{array}{c}\text { Preliminary Elevator Pitch Competition } \\
\qquad(3-5 \mathrm{pm})\end{array}$} \\
\hline 14 & \multicolumn{3}{|c|}{$\begin{array}{l}\text { Preliminary Project Pitch Competition } \\
\qquad(3-5 \mathrm{pm})\end{array}$} \\
\hline
\end{tabular}




\section{TG 421 Entrepreneurship Syllabus (One semester course)}

\begin{tabular}{|c|c|c|c|}
\hline Week & Topic /Workshop & Workshop & $\begin{array}{c}\text { Related } \\
\text { Deliverables }\end{array}$ \\
\hline 1 & $\begin{array}{l}\text { Introduction to Entrepreneurship \& } \\
\text { course overview }\end{array}$ & & \\
\hline 2 & $\begin{array}{l}\text { From the Business Model to the } \\
\text { Business Plan and } \\
\text { Elements of Project Management }\end{array}$ & & \\
\hline 3 & $\begin{array}{c}\text { Craft your value proposition: Elevator } \\
\text { Pitch and Mission Statement - Failures } \\
\text { in Entrepreneurship }\end{array}$ & $\begin{array}{l}\text { Lab \#1 } \\
\text { Workshop }\end{array}$ & $\begin{array}{l}\text { Submit Names of } \\
\text { team members and } \\
\text { Design Idea }\end{array}$ \\
\hline 4 & Understanding your Customer & $\begin{array}{l}\text { Lab \#2 - part } 1 \\
\text { Workshop }\end{array}$ & $\begin{array}{c}\text { Lab \# } 1- \\
\text { Value Proposition, } \\
\text { Mission Statement, } \\
\text { Gantt Chart \& Prelim. } \\
\text { Business Plan }\end{array}$ \\
\hline 5 & $\begin{array}{l}\text { Identify and analyze your industry, the } \\
\text { target sector and the type of business }\end{array}$ & & $\begin{array}{l}\text { Lab \# 2 - Competitive } \\
\text { intelligence part } 1 \\
\text { (Stakeholder needs } \\
\text { analysis) }\end{array}$ \\
\hline 6 & Positioning Your Venture & $\begin{array}{l}\text { Lab \#2 - part } 2 \\
\text { Workshop }\end{array}$ & \\
\hline 7 & $\begin{array}{l}\text { Avoiding mistakes in Entrepreneurship } \\
\text { by pursuing sustainable growth }\end{array}$ & & $\begin{array}{l}\text { Lab \# } 2 \text { - Competitive } \\
\text { intelligence part } 2 \\
\text { (Industry analysis \& } \\
\text { positioning) }\end{array}$ \\
\hline 8 & Intellectual Property & $\begin{array}{c}\text { Lab \#3 } \\
\text { Workshop }\end{array}$ & \\
\hline 9 & $\begin{array}{l}\text { Elevator Pitch Presentations } \\
\text { (based on signup sheets) }\end{array}$ & & \\
\hline 10 & $\begin{array}{c}\text { Review of Economics of a startup \& } \\
\text { Cost structure \& selling price of } \\
\text { product/service }\end{array}$ & & $\begin{array}{l}\text { Lab \# } 3 \text { - Intellectual } \\
\text { Property Lab due }\end{array}$ \\
\hline 11 & Raising Capital & $\begin{array}{c}\text { Lab \#4 } \\
\text { Workshop }\end{array}$ & \\
\hline 12 & Presentation Basics & & $\begin{array}{l}\text { Lab \# } 4 \text { - Financial } \\
\text { Lab }\end{array}$ \\
\hline 13 & $\begin{array}{l}\text { TA Review of Economics } \\
\text { (based on signup sheets) }\end{array}$ & & $\begin{array}{l}\text { Team Based Review } \\
\text { of Project Economics }\end{array}$ \\
\hline 14 & $\begin{array}{l}\text { FINAL PRESENTATIONS } \\
\text { (based on signup sheets) }\end{array}$ & & $\begin{array}{l}\text { Elevator/Project Pitch } \\
\text { and Final Presentation }\end{array}$ \\
\hline
\end{tabular}




\section{Appendix B}

\section{TG - 403-404 - Course Outcomes}

\begin{tabular}{|c|c|c|c|}
\hline $\begin{array}{l}\text { Stevens Outcome } \\
\text { Label }\end{array}$ & $\begin{array}{l}\text { ABET } \\
\text { a-k }\end{array}$ & Course outcome description & $\begin{array}{l}\text { Assessment } \\
\text { Tool }\end{array}$ \\
\hline 6. - Tools & $\mathrm{k}$ & $\begin{array}{l}\text { You are able to apply techniques and models to carry } \\
\text { out market research (demand analysis and revenues } \\
\text { estimation) and conduct simulated internal strategic } \\
\text { analysis (mission statement, project schedule) and } \\
\text { identify target customer and competitive intelligence, }\end{array}$ & $\begin{array}{l}\text { Final } \\
\text { Presentation }\end{array}$ \\
\hline 7. - Professionalism & $\mathrm{f}$ & $\begin{array}{l}\text { Identify stakeholders (clients, customers, etc.) and } \\
\text { work with these entities in an ongoing manner to } \\
\text { identify their needs and translate them into project } \\
\text { requirements. }\end{array}$ & $\begin{array}{l}\text { Stakeholders } \\
\text { Needs } \\
\text { Analysis }\end{array}$ \\
\hline 8. - Leadership & $\mathrm{d}$ & $\begin{array}{l}\text { You can explain the importance of leadership, and } \\
\text { experienced it, in the creation of a simulated new } \\
\text { venture (integrating different points of views and } \\
\text { managing conflict, persuading your peers as well as } \\
\text { investors/clients and customers of the value of your } \\
\text { proposals). }\end{array}$ & $\begin{array}{l}\text { Mid-term } \\
\text { Status } \\
\text { Presentation }\end{array}$ \\
\hline 9. - Teamwork & $\mathrm{d}$ & $\begin{array}{l}\text { You can explain the importance of teamwork and } \\
\text { team management, and experienced it, in the creation } \\
\text { of a simulated new venture (negotiating with your } \\
\text { team members, understanding the different roles and } \\
\text { functions played by different team members). }\end{array}$ & $\begin{array}{l}\text { Organizational } \\
\text { Chart }\end{array}$ \\
\hline 10. - Communication & $\mathrm{g}$ & $\begin{array}{l}\text { You are able to successfully communicate and } \\
\text { present a business idea to various stakeholders } \\
\text { (through effectively developing and writing various } \\
\text { things such as a presentation, Executive Summary, } \\
\text { Project/Elevator Pitch, etc) }\end{array}$ & $\begin{array}{l}\text { Lean Canvas } \\
\text { Business Plan }\end{array}$ \\
\hline 12. - Social Issues & $\mathrm{J}, \mathrm{h}$ & $\begin{array}{l}\text { You can explain critical insights offered by social } \\
\text { sciences for the analysis and process of simulated } \\
\text { venture creation including social and psychological } \\
\text { aspects in entrepreneurial decision-making, } \\
\text { customer's choice, and creation of effective } \\
\text { entrepreneurial teams. }\end{array}$ & $\begin{array}{l}\text { Mid-Term } \\
\text { Presentation }\end{array}$ \\
\hline 14. - Entrepreneurship & & $\begin{array}{l}\text { Assess and develop a business opportunity for } \\
\text { viability. }\end{array}$ & $\begin{array}{l}\text { Competitive } \\
\text { Intelligence }\end{array}$ \\
\hline 14. - Entrepreneurship & & $\begin{array}{l}\text { You can explain the interplay between technological } \\
\text { design and business processes necessary to nurture } \\
\text { new technologies from concept to commercialization. }\end{array}$ & $\begin{array}{l}\text { Financial } \\
\text { Analysis }\end{array}$ \\
\hline 14. - Entrepreneurship & & $\begin{array}{l}\text { You can explain the role of entrepreneurship in the } \\
\text { market economy as well as its' relevance to } \\
\text { engineering professionals, as prospective } \\
\text { entrepreneurs or in the context of corporate } \\
\text { entrepreneurship. }\end{array}$ & $\begin{array}{l}\text { Final } \\
\text { Presentation }\end{array}$ \\
\hline
\end{tabular}


TG - 421 - Course outcomes

\begin{tabular}{|c|c|c|c|}
\hline $\begin{array}{l}\text { Stevens Outcome } \\
\text { Label }\end{array}$ & $\begin{array}{l}\text { ABET } \\
\mathrm{a}-\mathrm{k}\end{array}$ & Course outcome description & $\begin{array}{l}\text { Assessment } \\
\text { Tool }\end{array}$ \\
\hline $\begin{array}{l}\text { 5. - Design } \\
\text { Assessment }\end{array}$ & $\mathrm{C}, \mathrm{h}$ & $\begin{array}{l}\text { You are able to rationally compare and contrast simulated } \\
\text { alternative venture projects through the combination of } \\
\text { engineering economics methods and industry/market } \\
\text { strategic analysis. }\end{array}$ & $\begin{array}{l}\text { Economics } \\
\text { Lab }\end{array}$ \\
\hline 6. - Tools & $\mathrm{k}$ & $\begin{array}{l}\text { You are able to apply techniques and models to carry out } \\
\text { market research (demand analysis, segmentation, and } \\
\text { revenues estimation). }\end{array}$ & $\begin{array}{l}\text { Competitive } \\
\text { Intelligence } \\
\text { Lab- part } 1\end{array}$ \\
\hline 6. - Tools & $\mathrm{k}$ & $\begin{array}{l}\text { You are able to apply techniques and models to conduct } \\
\text { simulated internal strategic analysis (Business model } \\
\text { description, costs analysis and structure, identification of } \\
\text { financial sources and financial planning). }\end{array}$ & $\begin{array}{l}\text { Lab } 1 \text { - } \\
\text { Value } \\
\text { Proposition, } \\
\text { Mission } \\
\text { Statement, } \\
\text { Gantt Chart } \\
\text { \& Prelim. } \\
\text { Business } \\
\text { Plan }\end{array}$ \\
\hline 6. - Tools & $\mathrm{k}$ & $\begin{array}{l}\text { You are able to carry out simulated competitive analysis } \\
\text { (identification and evaluation of target industry, } \\
\text { competitive intelligence, perceptual maps). }\end{array}$ & $\begin{array}{l}\text { Competitive } \\
\text { Intelligence } \\
\text { Lab- part } 2\end{array}$ \\
\hline 6. -Tools & $\mathrm{k}$ & $\begin{array}{l}\text { You are able to perform an intellectual property } \\
\text { assessment of your simulated product to analyze its } \\
\text { originality and identify the most suitable form of IP } \\
\text { protection for your project. }\end{array}$ & $\begin{array}{l}\text { Intellectual } \\
\text { Property } \\
\text { Lab }\end{array}$ \\
\hline 8. - Leadership & $\mathrm{d}$ & $\begin{array}{l}\text { You comprehend the importance of leadership, and } \\
\text { experienced it, in the creation of a simulated new venture } \\
\text { (development of a vision and mission for the venture, } \\
\text { integrating different points of views and managing } \\
\text { conflict, persuading your peers as well as investors and } \\
\text { customers of the value of your proposals). }\end{array}$ & $\begin{array}{l}\text { Final } \\
\text { Presentation }\end{array}$ \\
\hline 9. - Teamwork & $\mathrm{d}$ & $\begin{array}{l}\text { You comprehend the importance of teamwork and team } \\
\text { management, and experienced it, in the creation of a } \\
\text { simulated new venture (negotiating with your team } \\
\text { members, understanding the different roles and functions } \\
\text { played by different team members). }\end{array}$ & $\begin{array}{l}\text { Final } \\
\text { Presentation }\end{array}$ \\
\hline 10. - Communication & $g$ & $\begin{array}{l}\text { You are able to present a simulated business idea or } \\
\text { venture proposal through professional and widely adopted } \\
\text { business communication formats (elevator pitch, investors } \\
\text { presentations and compact display of venture financial } \\
\text { performances. }\end{array}$ & $\begin{array}{l}\text { Mid-term } \\
\text { Elevator } \\
\text { Pitch }\end{array}$ \\
\hline 12. - Social Issues & $\mathrm{J}, \mathrm{h}$ & $\begin{array}{l}\text { You comprehend critical insights offered by social } \\
\text { sciences for the analysis and process of simulated venture } \\
\text { creation including social and psychological aspects in } \\
\text { entrepreneurial decision-making, customer's choice, and } \\
\text { creation of effective entrepreneurial teams. }\end{array}$ & $\begin{array}{l}\text { Final } \\
\text { Elevator } \\
\text { Pitch }\end{array}$ \\
\hline $\begin{array}{l}\text { 14.- } \\
\text { Entrepreneurship }\end{array}$ & & $\begin{array}{l}\text { You understand the interplay between technological } \\
\text { design and business processes necessary to nurture new } \\
\text { technologies from concept to commercialization. }\end{array}$ & $\begin{array}{l}\text { Lab 1 - } \\
\text { Value } \\
\text { Proposition, } \\
\text { Mission } \\
\text { Statement, } \\
\text { Gantt Chart } \\
\text { \& Prelim. }\end{array}$ \\
\hline
\end{tabular}




\begin{tabular}{|l|l|l|l|}
\hline & & $\begin{array}{l}\text { Business } \\
\text { Plan }\end{array}$ \\
\hline $\begin{array}{l}\text { 14.- } \\
\text { Entrepreneurship }\end{array}$ & $\begin{array}{l}\text { You understand the role of entrepreneurship in the market } \\
\text { economy as well as its' relevance to engineering } \\
\text { professionals, as prospective entrepreneurs or in the } \\
\text { context of corporate entrepreneurship. }\end{array}$ & $\begin{array}{l}\text { Final } \\
\text { Presentation }\end{array}$ \\
\hline & & \\
\hline
\end{tabular}

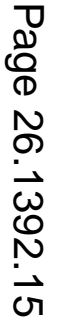

